\title{
Urban metabolism planning and designing approaches between quantitative analysis and urban landscape
}

\author{
Roberta Pistoni ${ }^{{ }^{*}}$ and Sophie Bonin ${ }^{2}$
}

\begin{abstract}
Introduction: Nowadays, urban metabolism (UM) is believed to provide new insights for more sustainable resource management in cities and their hinterlands. UM studies, however, focalize chiefly on quantitative resource input and output (e.g. energy, materials) and tend to neglect the element of space and the qualitative characteristics of the urban landscape. This paper explores the use of UM as a basis for planning and design, focusing on the design process and on landscape configuration, in an attempt to bridge the gap between such an approach and the perceptions of urban inhabitants.

Case description: Two case studies on the metropolitan scale based on UM quantification which aim to develop projects that can improve urban sustainability are analyzed: the International Architecture Biennale of Rotterdam and the Amsterdam Urban Pulse project. Subsequently, De Ceuvel is explored, an experimental neighborhood in Amsterdam that deployed the UM approach to develop a participatory design and implementation process.

Discussion and Evaluation: The method consists in a case study analysis centered on field work, document analysis, and semi-structured interviews with the designers involved, while the inhabitants' points of view are also polled on the neighborhood scale.

Conclusions: The key results highlight how the UM approach can be integrated with spatial design in two different ways, according to the scales implicated. On the metropolitan scale, UM provides a means of identifying key locations and proposing interventions that can improve a city's global metabolism. On the scale of the neighborhood, however, the UM approach aims to close the energy and material cycles on the design plot, though without necessarily connecting the neighborhood to the city network.
\end{abstract}

Keywords: Netherlands, Resource management, Urban landscape, Inhabitant, Perception, Designers, Sustainability

\section{Background}

Since the publication of "Our Common future" in 1987 (Commission and on Environment and Development 1987), the importance of sustainable development has been broadly recognized. Nowadays increasing urbanization and the concomitant problems of the depletion of

\footnotetext{
*Correspondence: r.pistoni@ecole-paysage.fr

1 LAREP, École Nationale Supérieure de Paysage de Versailles-

AgroParisTech, 10, Rue du Maréchal-Joffre, 78000 Versailles, France

Full list of author information is available at the end of the article
}

fossil fuels, climate change, and increasing pollution has highlighted the need for more efficient and sustainable resource management.

The awareness that the problems that we are facing today cannot be solved solely with technological solutions is becoming increasingly widespread (Pahl-Wostl 2007) and it is now realized that planning for a sustainable future presents a major challenge for both research and practice (Vandevyvere and Stremke 2012).

Meanwhile, the links between sustainable resource management and spatial planning have been recognized 
(Agudelo-Vera et al. 2011), and the fact that the spatial organization of cities and regions and their infrastructures influence resource management practices has been acknowledged (Bélanger 2009).

Urban metabolism (UM) is a concept, directly borrowed from biology and biochemistry and applied to urban studies (Wachsmuth 2012), that today suggests new paths towards city sustainability (Castán-Broto et al. 2012).

The history of the expression Urban Metabolism itself shows that what is at stake here is the advent of the environmental sciences-and not only engineeringin a field that was until now mainly political. The field of urban thinking has been dominated by social ideology or at best by concerns such as safety and hygiene, or socio-economic organization (e.g. resource proximity); in brief, considerations developed by humans for humans. It is hard not to see this as an outcome of Patrick Geddes' thinking about the city as a living organism or of the ideas of Christopher Alexander, which, if formulated differently, possess similar resonances (Batty and Marshall 2017). For urban metabolism thinking, however, the consequences of these ideas may emerge as the polar opposite what urban organicists advocated: not to privilege vernacular or spontaneous processes, but, on the contrary, to pilot, in accordance with scientific models, the future of urban forms. Though this rather overdraws the distinction between top-down and bottom-up policies in urban planning and design, the following case studies will help to rethink these positions in their complexity.

Developed in 1965 (Wolman 1965), UM describes the impact of the urban system on the environment and is defined as the total sum of processes for which cities mobilize, consume, and transform the resources they need to function and develop, together with the resultant waste and pollution (Barles 2008).

Urban metabolism has been primarily been deployed to calculate the amount of input and output of selected resources (e.g. energy, raw materials, water, phosphorus), using increasingly defined methods (e.g. Eurostat 2001) and commonly with no account taken of the spatial dimension (Kennedy et al. 2007) or the urban landscape in general. Furthermore, referring to landscape as defined by the European Landscape Convention (Council of Europe 2000), we use urban because the context of our inquiry consists of densely built-up areas (Berque 2006). Thinking about UM in the context of the urban landscape would thus make it possible to address the form of a city from the perspective of its spatial organization (Sanson 2007).

The relation between flow quantity and the nature of the city in question is addressed in only a few studies. To give one example, Duvigneaud, in his study of the
"Écosystème Urbs" (Duvigneaud and Denaeyer-De Smet 1977) in Brussels, shows how the large quantity of rainwater runoff pouring into sewers is due to "the predominance of stone or other hard and impermeable materials, as against soft and water-permeable soil".

The recognition of the connection between the spatial component of urban flow and the characteristics of the urban landscape opens up new paths for the UM approach to planning and design. UM is thus shifting from a descriptive picture, affording a global understanding of how an urban system works to a planning and design tool capable of providing operational strategies for more sustainable urban development (Kennedy et al. 2011).

The need to escape the "black box" city model neglecting urban networks that has long characterized UM studies (Zhang 2013), recognizes the role of designers such as landscape architects and urban planners in understanding resource flows in connection with land use and spatial quality regulations (Pincetl et al. 2012). In this regard, the FP7 project BRIDGE has developed a decision support system factoring in UM principles that inform the planning process (Chrysoulakis et al. 2013).

UM studies have chiefly been developed on the wider regional or metropolitan scale (Niza et al. 2009; Barles 2009), with only a handful of analyses on the local scale (Codoban and Kennedy 2008), mainly because of difficulties in data accessibility (Codoban and Kennedy 2008). Analyses on the metropolitan and wider scales are important for the general orientation and the definition of strategies for the city. At the same time, the neighborhood has a role to play in improving the metabolism of the city at large (Kennedy et al. 2005), because it remains the scale on which projects are implemented concretely.

Energy and material flows exist in cities, interacting to create economical and societal patterns as well as spatial and geographical patterns (Perrotti and Pouteau 2013). Models for flow management might be modified in keeping with energy transition and sustainability issues addressing from a new perspective, for example, in terms of waste recycling, the circular economy, energy and resource savings, renewable energy production, etc. The impact of such modifications will influence urban form (amenities, infrastructure), which is a key factor in any effort to consider or understand the extent of the transformation envisaged. In this context this research aims to analyze the planning and design process on two scales of projects advocating conscious resource management on the basis of an urban metabolism quantitative model so

\footnotetext{
1 “[L]a dominance de la pierre ou des matériaux durs et imperméables sur la terre molle et perméable à l'eau". Duvigneaud and Denaeyer-De Smet (1977), p 581.
} 
as to improve urban sustainability. The landscape configuration of these projects is similarly questioned, in order to investigate the role and perception of the inhabitants as end-users.

As an exercise in bridging the gap, employing complex quantitative models and integrating the perceptions and participation of the inhabitants calls for further inquiry, since modifications in energy, technology, and spatial management/planning choices brought by energy transition impact directly on the living environment of the inhabitants, as well as on their social norms and ways of life. Contrariwise, the perception of both the issues and the solutions that need to be developed also influences the options mentioned above and therefore the changes affecting the living environment.

\section{Three case studies on two scales in the Netherlands}

The research analyses case studies (Francis 2001) on the metropolitan scale in Rotterdam and Amsterdam and on the neighborhood scale in the latter city. The goal is to highlight differences and similarities in how projects can be developed and in their finalities. A protocol (Kaufmann 2011; Bryman 2012) has been set up that frames semi-structured interviews with the designers involved on the scales of the metropolis (architect/urban planner, landscape architect) and neighborhood (architect, landscape architect), to which are added an environmental engineer, involved on the neighborhood scale.

These professionals were questioned on the reasons for setting up this sort of project, about the processes involved, and on how collaboration is directed within the project team and the kinds of knowledge bases and skills applied. Furthermore, ten semi-structured interviews were undertaken with the inhabitants on the scale of the district. This number was decided upon after a measure of redundancy was detected in the answers. The interviews were undertaken in English. The findings from the interviews were triangulated with field study observations and design document analyses, such as studies and planning and design reports.

The choice of the Netherlands was motivated by that country's enduring tradition of spatial planning and design (Buitelaar and Bregman 2016) and by the fact that the perspectives of energy transition and sustainability are there actively encouraged by the public authorities through urban experimental projects (Masboungi 2016).

\section{Metropolitan scale and local landscape effects: increasing visibility for raising awareness}

We first analyze the "International Architecture Biennale of Rotterdam" (IABR) of 2014, Urban by Nature, which employed UM-related analysis in developing an urban design.
A group of stakeholders studied the metabolism of Rotterdam (Tillie et al. 2014), quantifying several types of flow (goods, people, waste, biota, energy, food, freshwater, etc.). This methodology opened up the abovementioned "black box", with the addition of several maps that represent the flows constituting Rotterdam's network through its infrastructure spatially. These maps, however, remain highly abstract and geometric, and features of the land (water, land, relief, etc.) are not evident (Fig. 1). We discern a focus on the flows that backgrounds the other characteristics of the area, despite the importance of these features for adequate spatial planning and design.

If the descriptive features of the area are lost in the flow map on the metropolitan scale, they reappear at the level of the project site. Indeed, even if flow analysis takes little account of the land features, it can still lead to the development of new planning and design principles that modify the landscape, at least in that it inserts new elements into the city.

Combined with the flow maps, UM quantification has improved the understanding of the geothermal potential of the region and demonstrated the extent of energy waste in the harbor. In consequence, technical elements have been designed, called Heat Hubs, which act as switch points for residual heat from the harbor and produces geothermal heat (Brugmans and Strien 2014). Located in the city in a regular square grid (Fig. 2), closer examination of the insertion of the Heat Hubs in the city shows that designers have adapted them as public amenities. For example, a Heat $H u b$ near a sports center also functions as a sports facility (Fig. 3). The visibility and use of these new technical facilities designed to ensure a more circular management of energy in the city is also believed to promote better understanding and even raise awareness among the inhabitants of the problem of urban resource management. As an architect interviewed argued regarding the design of the Heat Hubs: "You use it, it's your infrastructure, it's not from a faraway company that does some mystical stuff and sends you the bill. You can actually use it every day, if you want to, it's an open public space" (D1).

From the point of view of design methodology the designers also highlight how "the design part of the process wasn't very different from what we normally do, the difference being the starting point: the analysis of flows" (D1). The flow analysis maps help them focalize on quantitative aspects that are not necessarily central to the diagnostic processes normally rolled out by designers (architect, planner, etc.) that usually focus more on morphology, topography, land use, etc. In this respect, urban metabolism is perceived as an element in the project that can strength the role of designers who are not there "just to make nice places" (D1), but who might "make a 


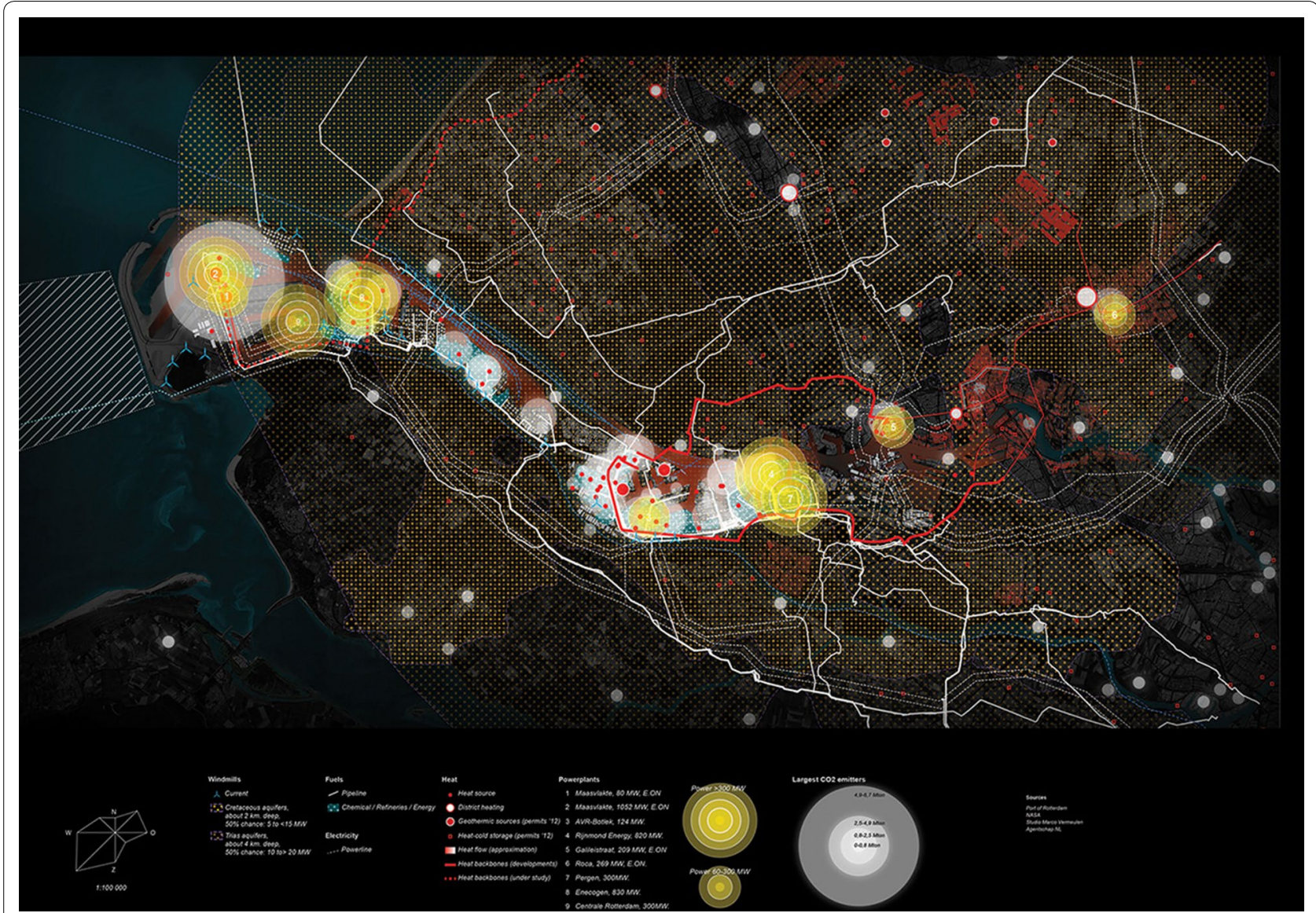

Fig. 1 Rotterdam metropolitan region energy flow map (Source: Tillie et al. (2014), pp 50-1)

meaningful link between science, engineering and spatial design" (D1).

The second project analyzed is the ongoing "Amsterdam Urban Pulse: Understanding the dynamics of resources flows in Amsterdam". This kick-off project by Advanced Metropolitan Solutions Institute (AMS) in Amsterdam started in 2014 and is coordinated by Wageningen University and developed by academic, public, and private partners.

The project studies Amsterdam's UM through adapted "Material Flow Analysis" (MAF), in order to detail improved quantitative methods for improved sustainable urban resource management (Voskamp et al. 2016b). At the same time, it also inquired into space-time information analysis (Voskamp et al. 2016a), with the goal of identifying the kinds of data that might provide planners and designers with meaningful information for implementing urban projects.

The Landscape Architecture Group at Wageningen University is involved in the coordination and development of the project by bringing a planning and design perspective, even though it is related more to spatio-temporal data availability and utility. This data are not translated into visible spatialized maps.

As one of the landscape architects interviewed involved remarked: "if we really want to design, it [UM] needs to have spatial references, but also temporal references. We have to know when flows are there and when they are not there" (D2). For the landscape architects the advantage of having designers involved in the process is to reflect on what closing the cycles might mean in terms of how housing, and more generally the urban landscape, might appear, when "working technically, but also esthetically and socially, and landscape architects can help bring those aspects into metabolism" (D2). However, the complexity of the challenge emerges with the understanding that collaboration between experts and the use of improved technical knowhow is a fundamental prerequisite. Designers can help to engage the inhabitants as end-users of the city by considering "how new solutions impact on people's daily life and how people might integrate it into their lifestyles" (D2). Here we found that the spatial component in the form of data analysis and the preoccupation of urban landscape effects is linked in the 


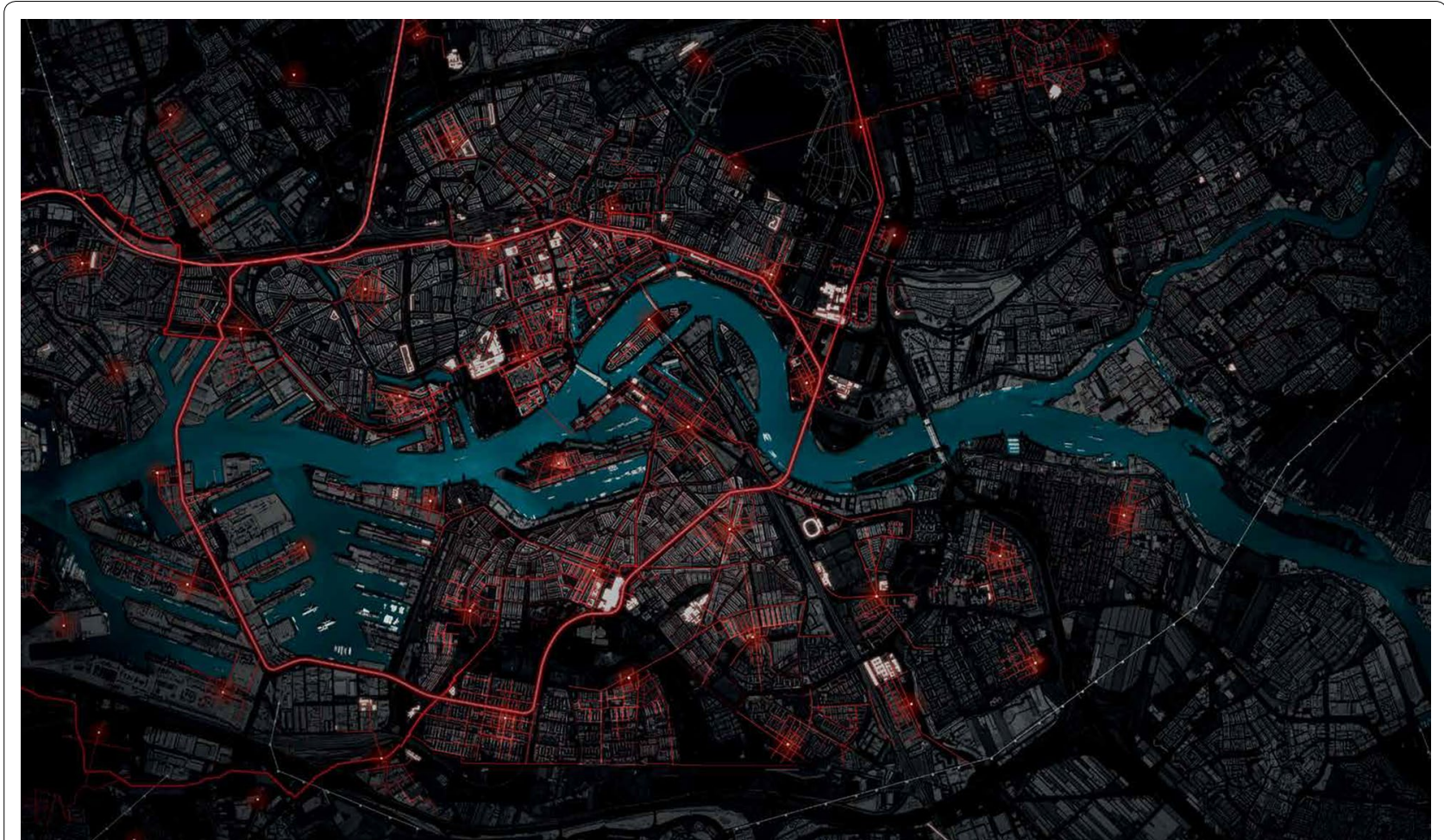

Fig. 2 Heat Hubs grid in Rotterdam (Source: Tillie et al. (2014), pp 108-9)

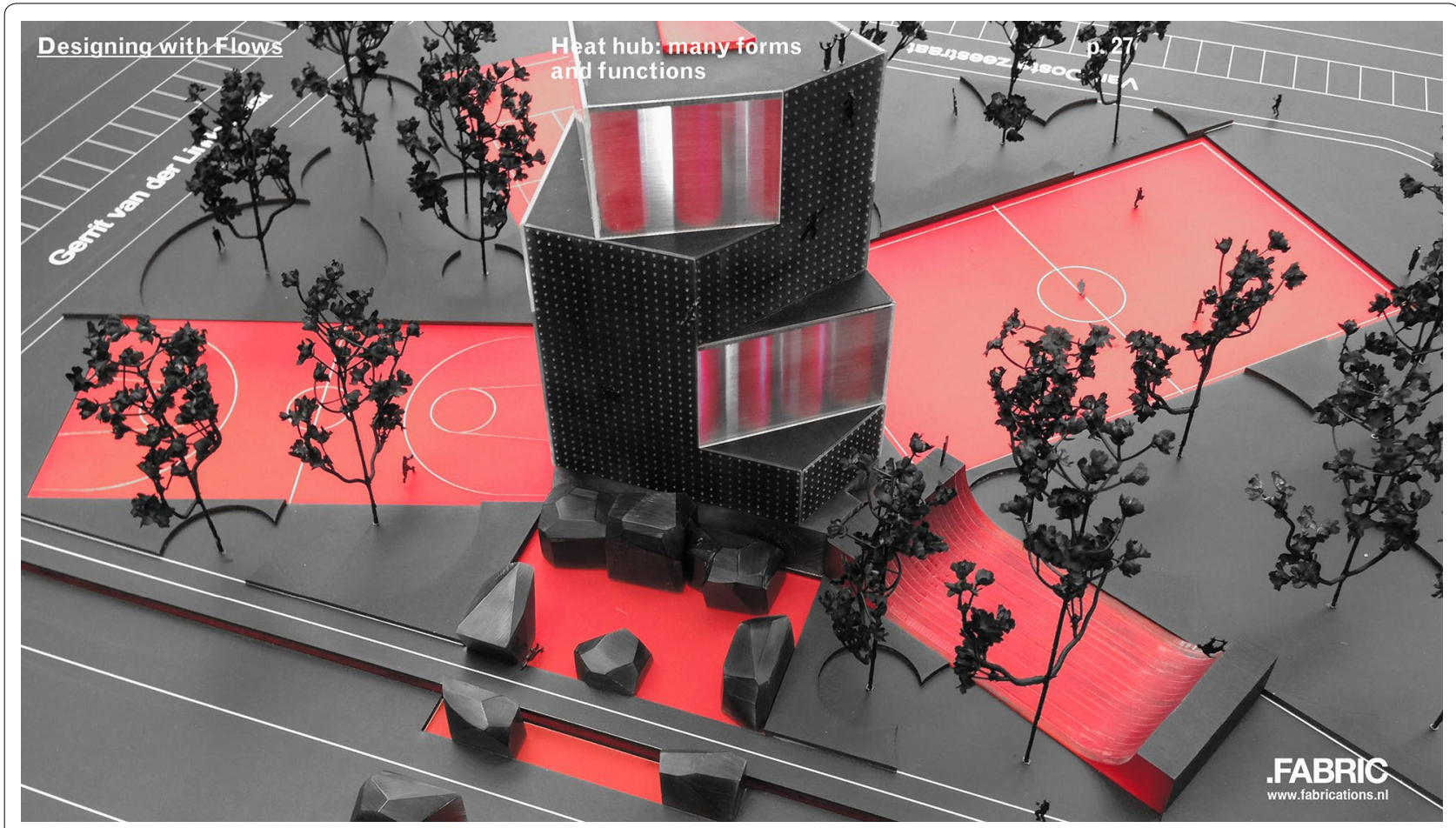

Fig. 3 Heat Hub with a sport public function (Source: Fabric http://www.fabrications.nl/) 
discourse of the designers with the topic of the inhabitants' awareness of resource management.

The purpose of these two projects was the same: to improve the UM of the city through careful planning and design for resource management and to advocate the importance of the contributions of designers. However, the projects differ in terms of process. The one in Amsterdam forms part of an academic debate, the method developed in the MFA affording a "scientific" credibility to the study. On the other hand, the Rotterdam project, as part of an architecture biennial, caters primarily for designers and for the public, where communication and graphics are central. This variance in approach also derives from the different actors involved. Researchers with an expertise in landscape architecture for Amsterdam Urban Pulse and designer offices for the Rotterdam projectthough both act in collaboration with technical experts. Nevertheless, for example, neither project studies in any depth the influence on the quantities of resource that can sustain urban life of urban form-such as the typology of the building stock, an aspect that strongly characterizes the urban landscape.

Another common feature is that designers emphasize the importance of inhabitant perception of and involvement in the urban landscape as something to be taken into account.

\section{A participative urban metabolism project: local scale and singular landscape creation}

The case analyzed on the neighborhood scale is $D e$ Ceuvel: an experimental project developed in the Buiksloterham district in the north of Amsterdam. This small neighborhood is one of the pilot projects for the creation of a "Circular Buiksloterham". In this project, the "UM scan" diagnostic served as a starting point to understand the current situation and to develop an UM quantification project able to pilot a design action plan for sustainably redeveloping the area in 2034 (Gladek et al. 2015).

De Ceuvel is a small office neighborhood. With a small budget and with occupancy limited to 10 years, the point of departure here was planning for the conscious and sustainable management of available resources, with the aim of ensuring their use and production became as circular as possible on the plot scale: "so to reuse, to produce on the spot was a good idea" (D3). However, potential synergies with the rest of the city do not seem to have been a matter of concern.

The project was the result of pooling the expertise of environmental engineers, landscape architects, and architects, together with the participation of the future users who were effectively "preselected" from among creative professionals engaged in sustainability and involved in constructing their own office environment.

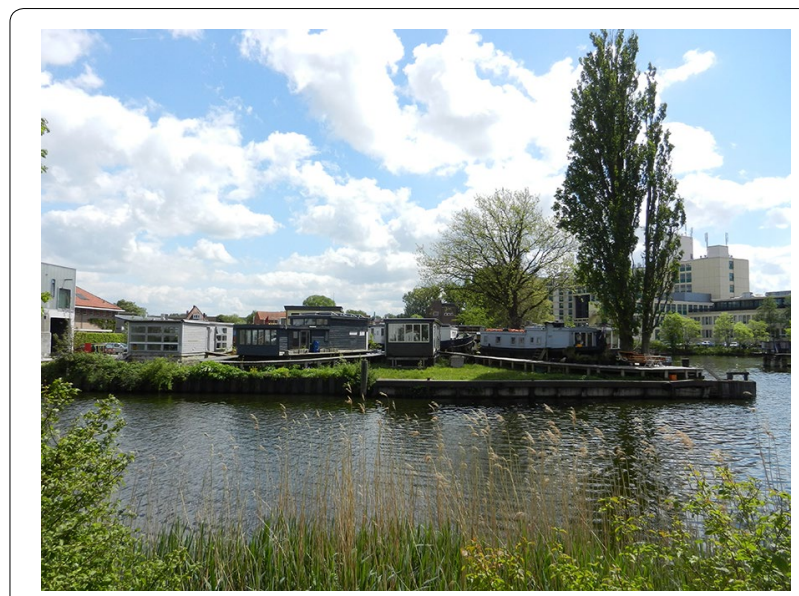

Fig. 4 Overview of De Ceuvel neighborhood (Source: Photo R. Pistoni April 2015)

As a result the neighborhood presents some particular characteristics, such as offices in old boats retrofitted in accordance with high efficiency standards (insulation, etc.) (Metaboliclab 2013) and placed on polluted nonaccessible land, where a phytoremediation system, called the "forbidden garden" designed by landscape architects has been set in train (Fig. 4). Access to the boat-offices is ensured by an elevated walkway, through which also run electricity cables and water supplies. Photovoltaic panels in conjunction with solar thermal collectors on the boats' roofs supply renewable energy. Due to its exceptional status as a "living lab" the neighborhood requires no sewers; water is processed through the largely green and permeable soil, while the grey waters are cleaned by a biofiltration system and dispersed into the ground (Fig. 5). Dry toilets are the norm and there is a specific area where waste is collected to produce compost.

The processes designed to achieve improved UM are different from those explored on the urban scale: here, direct action is key, creating and experimenting with the spatial design in response to local characteristics and resources, and not in consequence of top-down expertise. This is a process of "design du faire", as defined by Stéphane Vial (2010): "To do design is not only to think about doing; it is also doing for thinking". ${ }^{2}$ The results of such design activity become a form of knowledge, both in terms of the physical modification of the locality and as a mental and conceptual construct (Viganò 2010).

For instance, the architect explains that "the first time I came here it was just green and we thought it was so nice" (D3), but, since the ground was polluted, it was

\footnotetext{
2 "Faire du design, ce n'est pas seulement penser pour faire, c'est aussi faire pour penser". Vial (2010), p 90.
} 


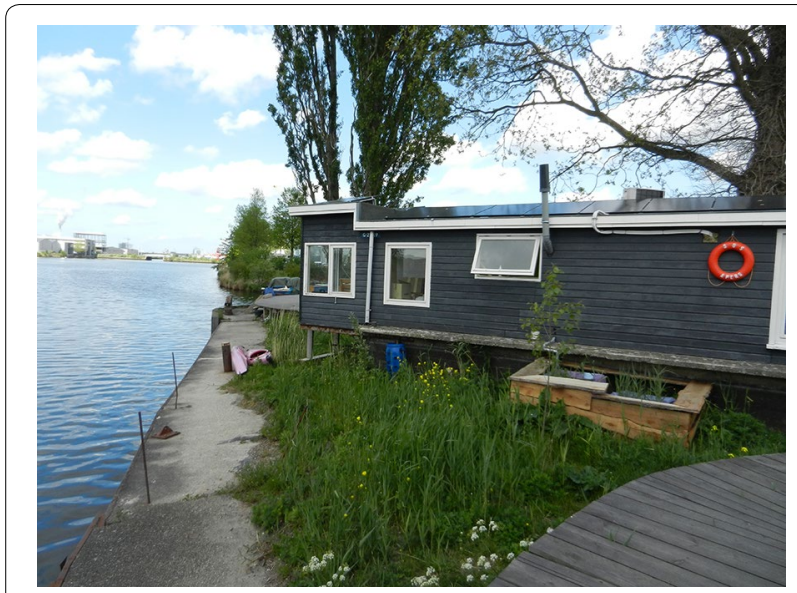

Fig. 5 Grey water bio-filter box outside an office-boat (Source: Photo R. Pistoni April 2015)

not possible to walk on it and it would have been expensive simply to cover it over. Furthermore, such a solution would compromise "the whole green atmosphere" (D3). So the landscape architect came up with the idea of phytoremediation in order "to use the pollution on the ground as an opportunity of doing something green and circular" (D3).

This approach has brought with it a measure of dysfunction, however. For example, in the shape of a wavy line, the elevated walkway was also designed to house electricity cable and fresh water ducts, so that the increased length owing to its sinuous form was not an especially efficient solution (Fig. 6).

The result of this process, designed from the outset to achieve resource circularity, is a peculiar urban landscape

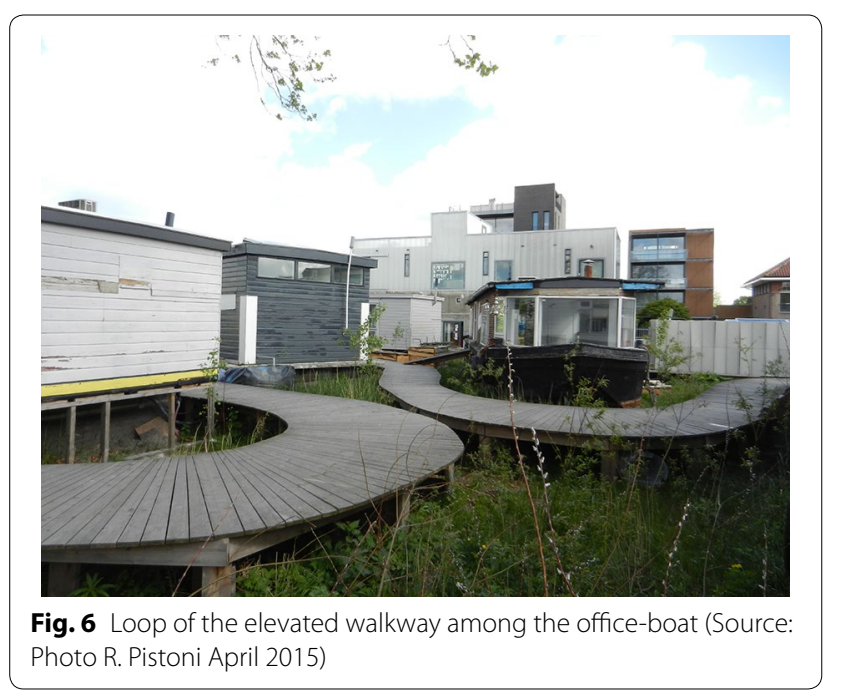

(Pistoni 2016), "where boats float in a green sea" (D4), "so different from the rest of the city" (H8), as was pointed out by both designers and occupants.

In order to study the end-user viewpoint with respect to the UM approach as it relates to their living environment and lifestyle we polled the inhabitants of De Ceuvel and analyzed their responses. Several themes emerged: (a) the relationship with the environment, (b) perceptions of the locality, (c) modifications in habitual behavior with respect to resource management. The remarks quoted are representative of the chief lines of thought shared by the interviewees.

The first finding is that users of De Ceuvel identify and relate strongly to their neighborhood. They are proud of the living environment they helped create and which reflects their need to build a more sustainable world and to enjoy being part of something that might contribute to a more sustainable way of life. ["It is like a glimpse of what a sustainable future will look like" (H6), "Here you have the feeling of making a successful difference" (H4)].

When we questioned the users as to what was most visible in resource management, they mostly focalized on the boats ["the boats of course on land!" (H7)] and the compost area where waste from the dry toilets is collected ["you can see these big beans" (H3)]. If the inhabitants did not particularly stress the plants depolluting the land, we found this aspect highlighted by designers ["phytoremediation, the cleaning of the soil, and you can see it very well, and where it is, not excavating, not covering it, as it normally does, and it's a circular things for us. Try to get something that's very linear, like taking away soil, more circular" (D4)]. They also emphasized water management.

If the landscape is perceived as positive and described as pleasant by all the interviewees ["as you can see, it is such a fabulous place!" (H8)], above all it is the significance of these spatial forms and the processes by with they were created that make the living environment really special for the users ["I enjoy this landscape, I'm even proud, because I know where it comes from and I'm part of its implementation" (H9)].

Furthermore, none of the interviewees affirmed that changing their habits in the neighborhood bothered them. Uppermost in most minds is the need to empty the dry toilet and carry its content to the compost area ["At the beginning, it's just a bit weird, everybody laughs, but after a while, it just becomes normal" H6]. A few talk also about having to place their desk close to the window in order not to waste electricity.

They are all aware of the resource management system and some also complain about several aspects that need to be improved: "we use water that goes into the grey 
water filtration system and after it's cleaned it goes to the ground. But we can't use it again in the boat! It's not circular yet!" (H7).

Project appropriation by the users is the basis of the success of the neighborhood design and implementation, while their appreciation and emotional relationship with the living environment has led to a virtuous loop of good practice in terms of resource management.

The exemplary character of De Ceuvel is emphasized by the visibility of the landscape created. This singular urban landscape has made the principles and strategies for UM improvement concrete and sharable. Such aesthetic materialization is perceived as positive by users who want to "educate other people and spread the word" (H7), in the hope "that somebody will be able to make such places somewhere else" (H10). The majority, however, recognize that "people have to get used to this kind of systems before being able to use it on a bigger scale" (H6).

This is a point also shared by the designers who argued for the reproducibility of the principles implemented in De Ceuvel in other locations: "it was quite easy, because there are many people who think in this way" (D4). Indeed, the de facto selection of users and the fact that it is a working area where people do not live day and night create a favorable context.

With regard to the users, the designers agreed that the process was one of the major characteristics of the project, even if they are of the opinion that UM has not really offered any new tools: "it's more a way of thinking" (D4). They focus on how UM might consolidate their role when intervening on a project. "What we think is that the aesthetics comes from a functional basis, so we have this metabolic argument now about circularity that is very strong, very logical" (D4). This point of view is shared by the engineer, who points out that "it's important that they [the designers] serve more than the goal of the design only" (E1) and that they add sustainability and efficiency.

Designers perceived co-construction with users positively: "everybody was enthusiastic during the building process!" (D3). This highlights how one of the aspects that has helped the project become successful was "to keep close to their [the end-users'] needs and to have as a goal comfort too, even in connection to circular thinking" (D4). The landscape architect added that the participation process helped "to make them very conscious about circular flows and the different systems used to manage them" (E1).

In conclusion, the ephemeral character of the project is a positive aspect of this laboratory of virtuous urban living, since it is reversible and has made little impact on the land and soil. The paradox is that, because of this very fact, as a model the project appears hard to transfer to most other urban project situations and difficult to implement politically and economically.

A sum up of the results has been developed in order to schematize the three cases study contribution (see Table 1).

\section{What might be learned from the urban metabolism approach?}

Despite the attention given the UM concept and the city over the last 50 years, stakeholders and designers are only recently beginning to embrace it for guiding projects. The progressive acknowledgement of urban environmental problems has turned the spotlight on UM as an operational base for sustainable urban design, even if its practical applications remain few.

In conclusion, it is clear that the more technical logic of UM in regards the planning and design process can be integrated in two different ways depending on the scale of its application. On the metropolitan scale, the understanding of spatial/pattern flows in an urban system can afford a general sense of where such projects might be advantageously located. The project, in this case, envisages networking various sites to improve the metabolism of the whole city.

On the other hand, on the scale of the district, the relationship with the rest of the city, though referred to, is not developed further. UM is rolled out to develop flow circularity on the plot, but without a clear and planned relation with other metropolitan areas. It is though crucial to implement such projects with due consideration of the scale, because in the urban system every zone is connected and the creation of a new district impacts directly on the metabolism of the entire city.

From the landscape angle, when applied on the local scale in an urban landscape, the impact of UM-a technical phenomenon-is remarkable, in the case of the Heat $H u b s$, and even more so with the De Ceuvel neighborhood. This singularity testifies to changes in resource management. As regards UM, project implementation also entails conscious resource management predicated on collaboration between several areas of competence. Technical expertise is required to formulate technological solutions, undertake quantitative calculations, and produce designs, so to translate these findings into aesthetic form so as to forge links with society.

Besides the designers, both architect and landscape architect, do not perceive this approach as altering their practice substantially, but rather as a tool for furnishing additional information. Furthermore, this technique forces them to think in terms of synergies across flows, locations, technologies, and scales. As a consequence, UM calls for increasingly deep knowledge of and specialization in the management of the different resources. 


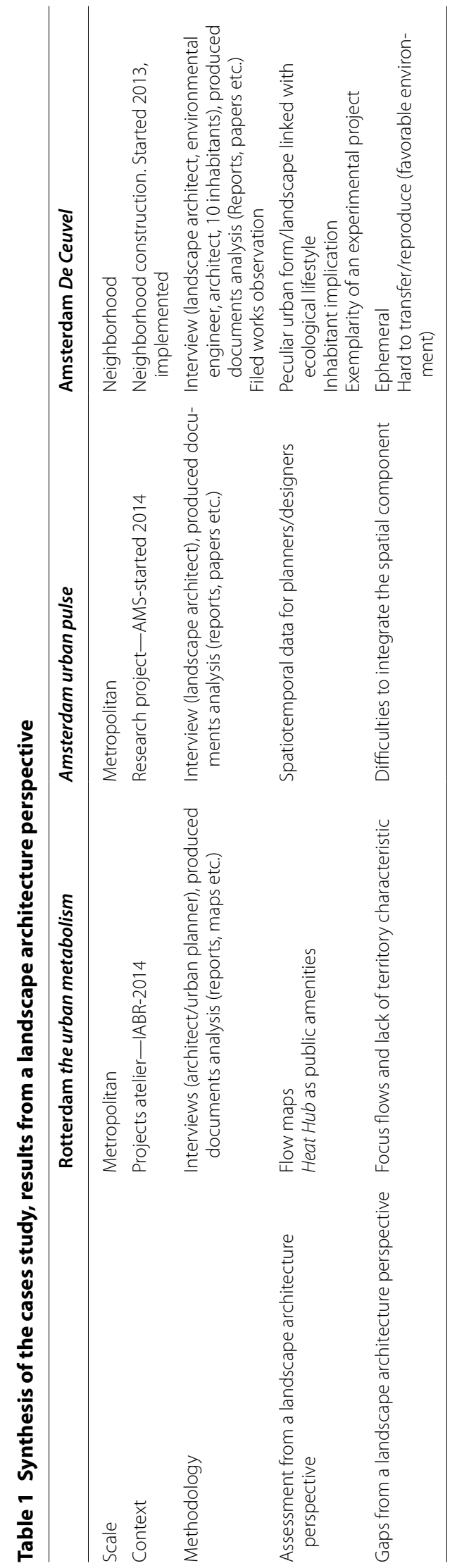


On the neighborhood scale, such a participatory project may prove a valuable aid in implementing the approach, though we argue that it chiefly functioned thanks to the quality of the environment and the type of end user involved. Nevertheless, this case study has foregrounded three major principles key to renewed urbanism: the necessity of seeking end-user adhesion early on in the project process; the richness of ephemeral occupations as demonstrations; and finally the ability of a modest and singular project to further awareness in more ecological lifestyles liable to be taken up more broadly.

Both on the metropolitan and neighborhood level the project benefits from a favorable institutional context that permitted experimentation in new resource management systems which could never otherwise been legally put into effect. The absence of sewers in De Ceuvel is a prime example.

Furthermore, many of the objectives discussed in our text resurface in the concept of the "sustainable city", offering a new angle on a phenomenon that itself is far from new. It addresses, among other things, the topic of urban space and resource recycling, the role of nature in the city, slow mobility, and the appropriation of the city by the inhabitants through participative practices (Theys and Emelianoff 2001).

Our starting hypothesis was that the scientific and quantitative models of UM might disconnect planning and design from the everyday uses and needs of the city, and lead to a markedly top-down approach. Our inquiry has nuanced and even reversed this idea. Designers continue to think primarily of how to integrate such new data into everyday life and do not feel "prisoners" of their models, but, on the contrary, seek in them inspiration for their approach to design.

It is possible that this was the case in our examples because the designers could play an influential role. It remains to be seen what would happen if resource flow data analysis was to lead directly to a planning model in the absence of the urban design process.

\section{Abbreviations}

UM: urban metabolism; D-1-2-3-4: interviews with designers; E1: interview with the engineer; $\mathrm{H} 1$ to $\mathrm{H} 10$ : interviews with De Ceuvel inhabitants.

\section{Authors' contributions}

Each author contributed to the research in terms of conception, research design, cross-checking data analysis and co-writing the paper. RP was primarily responsible for data collection, analysis and writing of the paper. Both authors read and approved the final manuscript.

\section{Author details}

1 LAREP, École Nationale Supérieure de Paysage de Versailles-AgroParisTech, 10, Rue du Maréchal-Joffre, 78000 Versailles, France. ${ }^{2}$ LAREP, École Nationale Supérieure de Paysage de Versailles, 10, Rue du Maréchal-Joffre, 78000 Versailles, France.

\section{Acknowledgements}

The materials has been collected during a research period in the LAR group at Wageningen University (Netherlands) under the supervision of Sven Stremke and Daniela Perrotti. We thank them for the support. This research has been the base for a Ph.D. project now ongoing, directed by LAREP-ENSP and LAR-WU.

\section{Competing interests}

The authors declare that they have no competing interests.

Availability of data and materials

The data are available upon request to the authors.

Consent for publication

Not applicable.

Ethics approval and consent to participate

Not applicable.

Funding

Not applicable.

\section{Publisher's Note}

Springer Nature remains neutral with regard to jurisdictional claims in published maps and institutional affiliations.

Received: 9 November 2017 Accepted: 13 December 2017

Published online: 22 December 2017

\section{References}

Agudelo-Vera CM, Mels AR, Keesman KJ, Rijnaarts HHM (2011) Resource management as a key factor for sustainable urban planning. J Environ Manag 92:2295-2303. https://doi.org/10.1016/j.jenvman.2011.05.016

Barles S (2008) Comprendre et maîtriser le métabolisme urbain et l'empreinte environnementale des villes. Annales des Mines 52:21-26

Barles S (2009) Urban metabolism of Paris and its region. J Ind Ecol 13:898-913. https://doi.org/10.1111/j.1530-9290.2009.00169.x

Batty M, Marshall S (2017) Thinking organic, acting civic: the paradox of planning for cities in evolution. Landsc Urban Plan 166:4-14. https://doi. org/10.1016/j.landurbplan.2016.06.002

Bélanger P (2009) Landscape as infrastructure. Landsc J 28:79-95. https://doi. org/10.3368/lj.28.1.79

Berque A (ed) (2006) Mouvance Il: du jardin au territoire: soixante-dix mots pour le paysage. Editions de la Villette, Paris

Brugmans G, Strien J (eds) (2014) IABR 2014: urban by nature. IABR, Rotterdam

Bryman A (2012) Social research methods, 4th edn. Oxford University Press, Oxford, New York

Buitelaar E, Bregman A (2016) Dutch land development institutions in the face of crisis: trembling pillars in the planners' paradise. Eur Plan Stud 24:1281-1294. https://doi.org/10.1080/09654313.2016.1168785

Castán-Broto V, Allen A, Rapoport E (2012) Interdisciplinary perspectives on urban metabolism. J Ind Ecol 16:851-861. https://doi. org/10.1111/j.1530-9290.2012.00556.x

Chrysoulakis N, Lopes M, San José R et al (2013) Sustainable urban metabolism as a link between bio-physical sciences and urban planning: the BRIDGE project. Landsc Urban Plan 112:100-117. https://doi.org/10.1016/j. landurbplan.2012.12.005

Codoban N, Kennedy C (2008) Metabolism of neighborhoods. J Urban Plan Dev 134:21-31. https://doi.org/10.1061/(ASCE)0733-9488(2008)134:1(21)

Council of Europe (2000) European landscape convention. Council of Europe, Florence

Duvigneaud P, Denaeyer-De Smet S (1977) L'écosystème urbain bruxellois. In: Duvigneaud $P$, Kestemont $P$ (eds) Productivité biologique en Belgique. Editions Duculot, Paris, pp 581-599

Eurostat (2001) Economy-wide material flow accounts and derived indicators. A methodological guide. Europa server. http://ec.europa.eu/eurostat/ documents/1798247/6191533/3-Economy-wide-material-flow- 
accounts...-A-methodological-guide-2001-edition.pdf/. Accessed 18 Aug 2017

Francis M (2001) A case study method for landscape architecture. Landsc J 20:15-29. https://doi.org/10.3368/lj.20.1.15

Gladek E, van Odijk S, Theuws P, Herder A (2015) Transitioning Amsterdam to a circular city. Circular Buiksloterham. http://buiksloterham.nl/engine/ download/blob/gebiedsplatform/69870/2015/28/CircularBuiksloterham_ENG_FullReport_05_03_2015.pdf?app=gebiedsplatform \&class $=90$ 96\&id=63\&field $=69870$. Accessed 16 April 2015

Kaufmann J-C (2011) L'entretien compréhensif-L'enquête et ses méthodes, 3e édition. Armand Colin, Paris

Kennedy C, Miller E, Shalaby A et al (2005) The four pillars of sustainable urban transportation. Transport Rev 25:393-414. https://doi. org/10.1080/01441640500115835

Kennedy C, Cuddihy J, Engel-Yan J (2007) The changing metabolism of cities. J Ind Ecol 11:43-59. https://doi.org/10.1162/jie.2007.1107

Kennedy C, Pincetl S, Bunje P (2011) The study of urban metabolism and its applications to urban planning and design. Environ Pollut 159:19651973. https://doi.org/10.1016/j.envpol.2010.10.022

Masboungi A (2016) Le génie d'Amsterdam: opportunité, agilité, inventivité. Parentheses, Marseilles

Metaboliclab (2013) Cleantech playground: a cleantech utility in Amsterdam North. Metaboliclab, Amsterdam

Niza S, Rosado L, Ferrão P (2009) Urban metabolism: methodological advances in urban material flow accounting based on the lisbon case study. J Ind Ecol 13:384-405. https://doi.org/10.1111/j.1530-9290.2009.00130.x

Pahl-Wostl C (2007) The implications of complexity for integrated resources management. Environ Model Softw 22:561-569. https://doi. org/10.1016/j.envsoft.2005.12.024

Perrotti D, Pouteau S (2013) Nature urbaine en projets. In: Chomarat-Ruiz C (ed) Le vivant et son énergie: cultiver les paysages urbains de la sobriété, 1st edn. Archibooks/Bookstorming, Paris

Pincetl S, Bunje P, Holmes T (2012) An expanded urban metabolism method: toward a systems approach for assessing urban energy processes and causes. Landsc Urban Plan 107:193-202. https://doi.org/10.1016/j. landurbplan.2012.06.006
Pistoni R (2016) Application of urban metabolism approach in energy landscape design. In: Bauer P, Collender M, Jakob M (eds) Bridging the gap. ECLAS Conference 2016, Rapperswil, Switzerland. HSR Hochschule für Technik Rapperswil, Rapperswil

Sanson P (2007) Le paysage urbain: représentations, significations, communication. L'Harmattan, Paris

Theys J, Emelianoff C (2001) Les contradictions de la ville durable. Le Débat 1:122-135

Tillie N, Klijn O, Frijters E, et al (eds) (2014) Urban metabolism. Sustainable development of Rotterdam, pp 50-109

Vandevyvere H, Stremke S (2012) Urban planning for a renewable energy future: methodological challenges and opportunities from a design perspective. Sustainability 4:1309-1328. https://doi.org/10.3390/su4061309

Vial S (2010) Court traité du design. PUF, Paris

Viganò P (2010) I territori dell'urbanistica: il progetto come produttore di conoscenza. Officina Edizioni, Rome

Voskamp IM, Spiller M, Stremke S et al (2016a) Space-time information analysis for resource-conscious urban planning and design: a stakeholder based identification of urban metabolism data gaps. Resour Conserv Recycl. https://doi.org/10.1016/j.resconrec.2016.08.026

Voskamp IM, Stremke S, Spiller M et al (2016b) Enhanced performance of the Eurostat method for comprehensive assessment of urban metabolism: a material flow analysis of Amsterdam. J Ind Ecol. https://doi.org/10.1111/ jiec.12461

Wachsmuth D (2012) Three ecologies: urban metabolism and the society-nature opposition. Sociol Quart 53:506-523. https://doi. org/10.1111/j.1533-8525.2012.01247.x

Wolman A (1965) The metabolism of cities. Sci Am 213:179-190

World Commission on Environment and Development (1987) Our common future. Oxford University Press, Oxford

Zhang Y (2013) Urban metabolism: a review of research methodologies. Environ Pollut 178:463-473. https://doi.org/10.1016/j.envpol.2013.03.052

\section{Submit your manuscript to a SpringerOpen ${ }^{\circ}$ journal and benefit from:}

- Convenient online submission

- Rigorous peer review

- Open access: articles freely available online

- High visibility within the field

- Retaining the copyright to your article

Submit your next manuscript at $\boldsymbol{\nabla}$ springeropen.com 